\title{
Anatomy of the utero-ovarian lymphatic network and the composition of afferent lymph in relation to the establishment of pregnancy in the sheep and goat
}

\author{
L. D. Staples, I. R. Fleet and R. B. Heap \\ A.R.C. Institute of Animal Physiology, Babraham, Cambridge CB2 4AT, U.K.
}

\begin{abstract}
Summary. Lymphatic vessels draining the uterus and ovaries were located within the mesometrium and along the utero-ovarian pedicle by injection of marker dyes into the uterine wall and/or ovary of sheep and goats. Afferent lymphatics drained from the uterus towards the utero-ovarian pedicle and alongside the uterine artery, while 4-12 ovarian lymphatics emerged from the sub-ovarian plexus. A complex lymphatic network was formed in the region of the utero-ovarian pedicle by anastomosis between uterine and ovarian lymphatics. Mixed lymph carried in ducts alongside the uterine artery and in the utero-ovarian pedicle drained into the medial iliac node(s) and lumbo-aortic nodes, respectively. There was no evidence for retrograde lymph flow between the uterus and ovaries, but the close proximity of utero-ovarian lymphatics and the ovarian artery may provide an additional pathway for countercurrent diffusion of prostaglandin F-2 $\alpha$.

Afferent lymph collected after chronic cannulation of utero-ovarian ducts ipsilateral to an ovary bearing a corpus luteum contained a mean progesterone concentration which was 10 - to 1000 -fold higher than that in jugular vein plasma between 15 and 45 days of gestation. Uterine lymph collected after cannulation of utero-ovarian ducts followed by ipsilateral ovariectomy had a progesterone value equivalent to that in plasma. Protein concentration in utero-ovarian and uterine lymph was between 85 and $90 \%$ of that of plasma, while $\mathrm{Na}$ concentration was slightly higher, and $\mathrm{Cl}$ concentration slightly lower than that of plasma. The concentration of $\mathrm{K}$ was similar in both biological fluids, confirming that tissue damage of cannulated vessels was negligible. Cell numbers in utero-ovarian and ovarian lymph were low (200 leucocytes $/ \mathrm{mm}^{3}$ ) and consisted mostly of lymphocytes (>94\%). These studies show that leucocytes in lymph are exposed to a high concentration of progesterone, and possibly other related steroids, in the uteroovarian network which is adjacent to an ovary containing a corpus luteum.
\end{abstract}

\section{Introduction}

In a comprehensive description of ovarian lymphatics in the sheep, Morris \& Sass (1966) showed that a profuse network of highly permeable lymphatic ducts develops within the corpus luteum during the luteal phase of the oestrous cycle and in early pregnancy. After traversing the ovary, these lymphatics join in the region of the hilus (subovarian plexus) to form 4-12 main vessels which drain from the ovary and are joined by lymphatics from the proximal half of the 
oviduct. The lymphatics which drain the ovary are mainly associated with the utero-ovarian vascular pedicle and, because the active corpus luteum has a very high lymph flow (Morris \& Sass, 1966), these ducts are much enlarged during the luteal phase and pregnancy.

The corpus luteum is essential for the maintenance of gestation until about Day 50 in sheep (Casida \& Warwick, 1945; Denamur \& Martinet, 1955) and throughout pregnancy in the goat (Drummond-Robinson \& Asdell, 1926; Meites, Webster, Young, Thorp \& Hatch, 1951). During these periods it is the major source of progesterone (Short \& Moore, 1959; Linzell \& Heap, 1968; Ricketts \& Flint, 1980). Progesterone synthesized by the corpus luteum is secreted predominantly into the ovarian vein and only about $10 \%$ appears in the lymphatic drainage (Lindner, Sass \& Morris, 1964). Although ovarian lymph is not a major route of steroid secretion, it contains a high concentration of progesterone (up to $2.05 \mu \mathrm{g} / \mathrm{ml}$ ) during the mid-luteal phase of the oestrous cycle (Lindner et al., 1964).

The luteal secretion of progesterone is terminated towards the end of the oestrous cycle by the action of the uterine luteolysin, prostaglandin (PG) F-2 $\alpha$ (Goding, 1974). PGF-2 $\alpha$ is believed to be transferred locally from the uterine vein to the ipsilateral ovarian artery by a countercurrent transfer mechanism (McCracken et al., 1972; Land, Baird \& Scaramuzzi, 1976). However, the possibility of transfer of PGF- $2 \alpha$ from uterine lymphatics to the ovarian vasculature has not been excluded, and Kotwica (1980) suggests that lymphatic pathways may be involved in the pig. Morris \& Sass (1966) found no evidence for connections between the "lymphatics draining the ovary and those draining the uterus itself", whereas Meckley \& Ginther (1969) briefly indicated that anastomoses existed in certain sheep but not in others. In view of this discrepancy we have re-examined the anatomy of the uterine and ovarian lymphatic vessels in the sheep. We have also examined comparable lymphatics in the goat. Since constituents of lymph may be important in the local immunoprotection of the fetal allograft, a further objective of this study was to examine the chemical composition and progesterone concentration of afferent lymph collected after chronic cannulation of lymphatics draining the reproductive tract in the first third of gestation. Measurements of electrolytes were performed to confirm the lack of cell damage.

\section{Materials and Methods}

\section{Animals}

Seventeen mature Friesland and Clun Forest ewes and 2 Saanen goats were used from the Institute. The day of mating was designated Day 0 of pregnancy.

\section{Localization of lymphatic pathways and cannulation of ducts}

Anaesthesia was induced by intravenous injection of pentobarbitone sodium (Sagatal: May \& Baker, Dagenham, U.K.) or thiopentone sodium (Brietal: Elenko Products, Basingstoke, U.K.) and maintained with $1 \%$ halothane (Fluothane; ICI Pharmaceuticals, Macclesfield, U.K.) in oxygen in a closed-circuit. The reproductive tract was exposed at midventral laparotomy using a Devine retractor. For anatomical studies, lymphatic ducts draining the ovary and uterus were localized in some animals by the injection of $100-200 \mu \mathrm{l}$ Evans Blue $(0.5 \%$ in saline, $9 \mathrm{~g}$ $\mathrm{NaCl} / 1)$ into the corpus luteum and beneath the serosal layer of the uterine wall. In other animals alternate injections of Alcian yellow (G. T. Gurr, London, U.K., saturated supernatant in saline) and Evans blue dye solutions were made into uterine and ovarian sites. Dye solutions were sterilized by Millipore filtration $(0.22 \mu \mathrm{m})$. Sites of mixing of uterine and ovarian lymph were identified by the presence of green lymph in certain vessels along the utero-ovarian pedicle. For cannulation of afferent lymphatics, all ducts, visible after injection of Evans blue into uterine tissue only, were ligated about $6-10 \mathrm{~cm}$ distal to the ovary. A single duct was selected for 
cannulation on the basis of size and accessibility and the slightly tapered end of a cannula (polyvinylchloride, $0.85 \mathrm{~mm}$ i.d. $\times 1.27 \mathrm{~mm}$ o.d.: Dural Plastics, Dural, New South Wales, Australia) was passed into the duct towards the uterus and through at least one valve so that the tip of the cannula was located between two lymphatic valves. The cannula was protected by an outer sleeve of Silastic tubing (Dow Corning, Midland, Michigan, U.S.A.) along its length, secured at the site of cannulation to the broad ligament, and exteriorized through the flank.

The tract was handled as little as possible during surgery to minimize infiltration of erythrocytes into lymph which is known to reduce the success of the cannulated preparation. After operation, animals received an intramuscular injection of 600000 i.u. procaine penicillin ( $2 \mathrm{ml}$ Duphapen: Duphar Veterinary Ltd, Southampton, U.K.). They were penned individually and fed hay ad libitum and approximately $400 \mathrm{~g}$ concentrates per day.

\section{Collection of samples}

Lymph was collected in a $50 \mathrm{ml}$ plastic centrifuge tube which was supported in an elastic pouch attached to the flank (Lascelles \& Morris, 1961) and contained 100 units diluted heparin (0.1 ml: Weddel Pharmaceuticals Ltd, London, U.K.). Collecting tubes were either replaced twice during each $24-\mathrm{h}$ period, or lymph was continuously removed from the collecting tube by peristaltic pump to heparinized glass tubes in a refrigerated fraction collector. In the latter experiments pooled samples were obtained automatically over consecutive 1 or $2 \mathrm{~h}$ intervals. Jugular venous blood was also collected from each animal at about 10:00 h on each day.

\section{Determination of lymph flow rate and leucocyte density}

Lymph flow rate $(\mathrm{ml} / \mathrm{h})$ was determined gravimetrically. Leucocyte numbers were determined (after dispersing cells by agitation) by counting $5 \times 0.1 \mathrm{~mm}^{3}$ grid volumes in a haemocytometer. Cells were then removed from the lymph by centrifugation $(10 \mathrm{~min}$ at $2000 \mathrm{~g}$, $4^{\circ} \mathrm{C}$ ) before dividing the lymph into 6 separate aliquots for storage at $-10^{\circ} \mathrm{C}$. Differential counts were performed on smears of the cell sediment after staining with Knyvett-Gordon differential stain (G. T. Gurr).

\section{Analyses}

Inorganic ions. Sodium and potassium concentrations were measured simultaneously by flame photometry against a lithium sulphate standard (Berry, Chappell \& Barnes, 1946; AAII auto-analyzer, Technicon Instrument Co. Ltd, U.K.). Chloride concentrations were determined in undiluted samples of cell-free lymph and in plasma by coulometric titration (Radiometer CMT-10 Chloride Titrator, Copenhagen, Denmark) against a $\mathrm{KCl}$ standard.

Proteins. Protein concentrations were measured in 100-200-fold diluted samples by the technique of Lowry, Rosebrough, Farr \& Randall (1951) using an automated procedure.

Progesterone. Progesterone was measured in lymph and plasma by the radioimmunoassay procedure described by Ricketts, Galil, Ackland, Heap \& Flint (1980). Progesterone was extracted from $50 \mu \mathrm{l}$ appropriately diluted lymph or plasma by shaking for $10 \mathrm{~min}$ with $5 \mathrm{ml}$ petroleum ether (b.p. $40-60^{\circ} \mathrm{C}$ ). The aqueous layer was frozen by standing extraction vials on solid $\mathrm{CO}_{2}$, the organic phase was decanted, dried under a stream of nitrogen, and its progesterone content measured as described previously (Ricketts et al., 1980). The antiserum 18 No. 2, kindly supplied by $\operatorname{Dr}$ A. P. F. Flint of this Institute, was raised in a sheep immunized against progesterone-1 $1 \alpha$-hemisuccinyl-bovine serum albumin. Antiserum was diluted to 1:5000 and showed a high specificity for progesterone; the extent of cross-reactions with other steroids was $<4.0 \%$ (Sheldrick, Mitchell \& Flint, 1980). The labelled ligand, $\left[1 \alpha, 2 \alpha(\mathrm{n})-{ }^{3} \mathrm{H}\right]$ progesterone (sp. act. $49 \mathrm{Ci} / \mathrm{mmol}$ ), was dissolved in $0.05 \mathrm{M}$-phosphate buffer to give a mean radioactivity of about 200000 d.p.m./ml. 
Extraction efficiencies from lymph and plasma were 96.5 and $95.4 \%$, respectively; sensitivity (determined from $2 \times$ s.d. about the zero-binding point) was $40 \mathrm{pg} / \mathrm{ml}$ lymph and 28 $\mathrm{pg} / \mathrm{ml}$ plasma (i.e. $<10 \mathrm{pg} / \mathrm{tube}$ ). The estimation of known amounts of progesterone added to uterine lymph was $0.97 \pm 0.10$ (for $1 \mathrm{ng} / \mathrm{ml}$ added, $n=8) ; 1.77 \pm 0.1(2 \mathrm{ng} / \mathrm{ml}, n=10) ; 3.60$ $\pm 0.22(4 \mathrm{ng} / \mathrm{ml}, n=8) ; 34$ and $35(50 \mathrm{ng} / \mathrm{ml}, n=2) ; 430$ and $446(500 \mathrm{ng} / \mathrm{ml}, n=2)$, and 956 and $1006(1000 \mathrm{ng} / \mathrm{ml}, n=2) \mathrm{ng} / \mathrm{ml}$. The coefficients of variation within and between assays were 12 and $17 \%$, respectively (amount added to popliteal lymph $4 \mathrm{ng} / \mathrm{ml} ; n=3$ within assays, $n=8$ between assays).

\section{Results}

\section{Anatomy of utero-ovarian network}

Clear lymphatic vessels were visible in the utero-ovarian pedicle of sheep and goats when a functional corpus luteum was present in the adjacent ovary, but without dye injections it was frequently difficult to ascertain their origin. The injection of Evans blue into the upper half of the
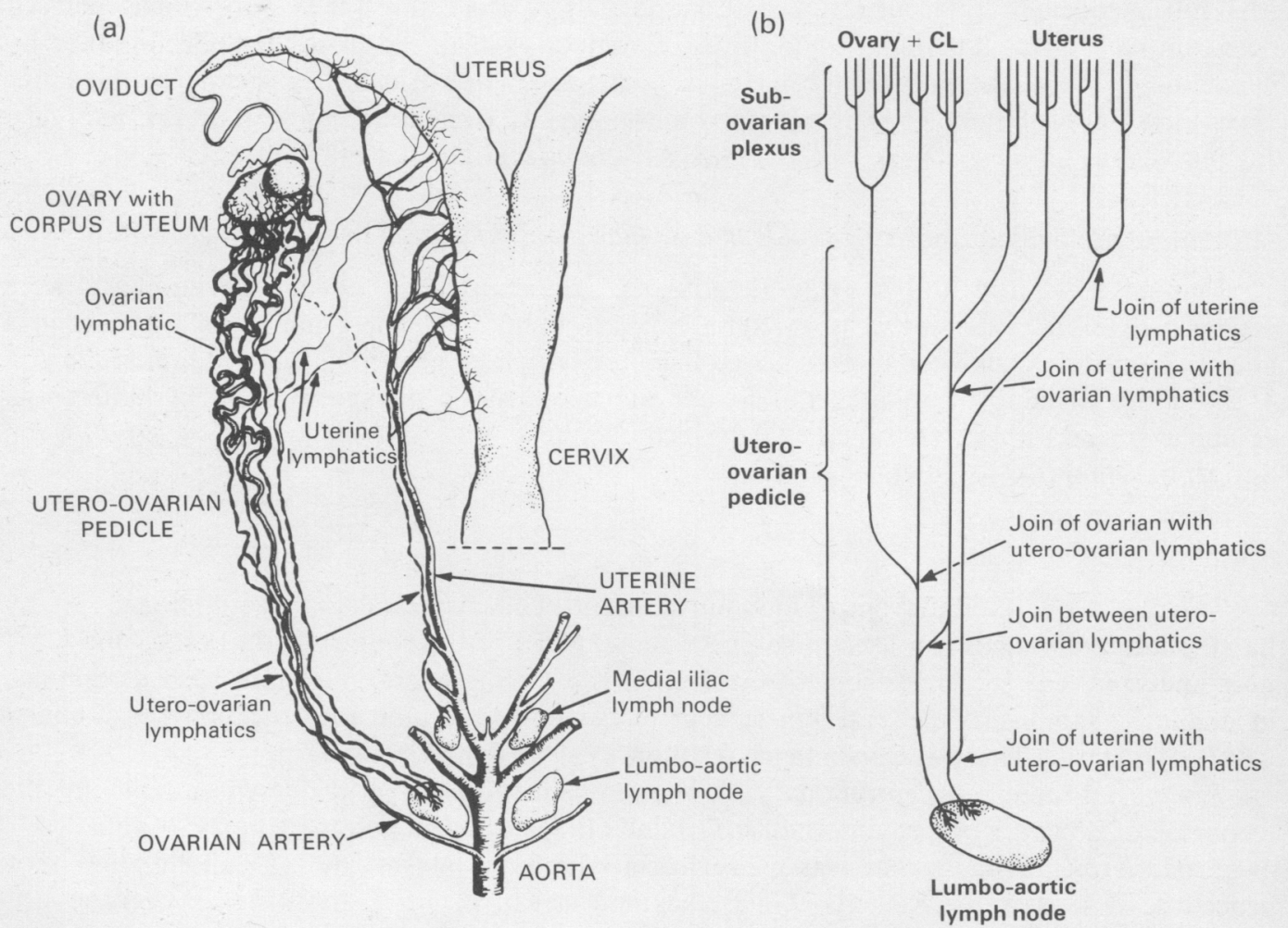

Text-fig. 1. (a) Composite drawing showing the major pathways in sheep of lymphatic drainage from the ovary and uterus along the utero-ovarian pedicle to the lumbo-aortic node(s) and beside the uterine artery to the medial iliac lymph node(s). The interconnections between uterine and ovarian ducts to form the utero-ovarian lymphatic network are shown and also the connection (broken line) between an ovarian and uterine lymphatic parallel to the uterine artery. Valves in the lymphatic vessels are indicated as irregular narrowing of the black lines while the ovarian and uterine arterial supplies (adapted from Habel, 1964) are shown as shaded ducts. The uterus is shown reflected about the broken line near the cervix to allow for clearer portrayal of the lymphatic and vascular pathways. (b) Schematic diagram showing the anastomoses which have been observed between ovarian, uterine and utero-ovarian lymphatics along the utero-ovarian pedicle. 

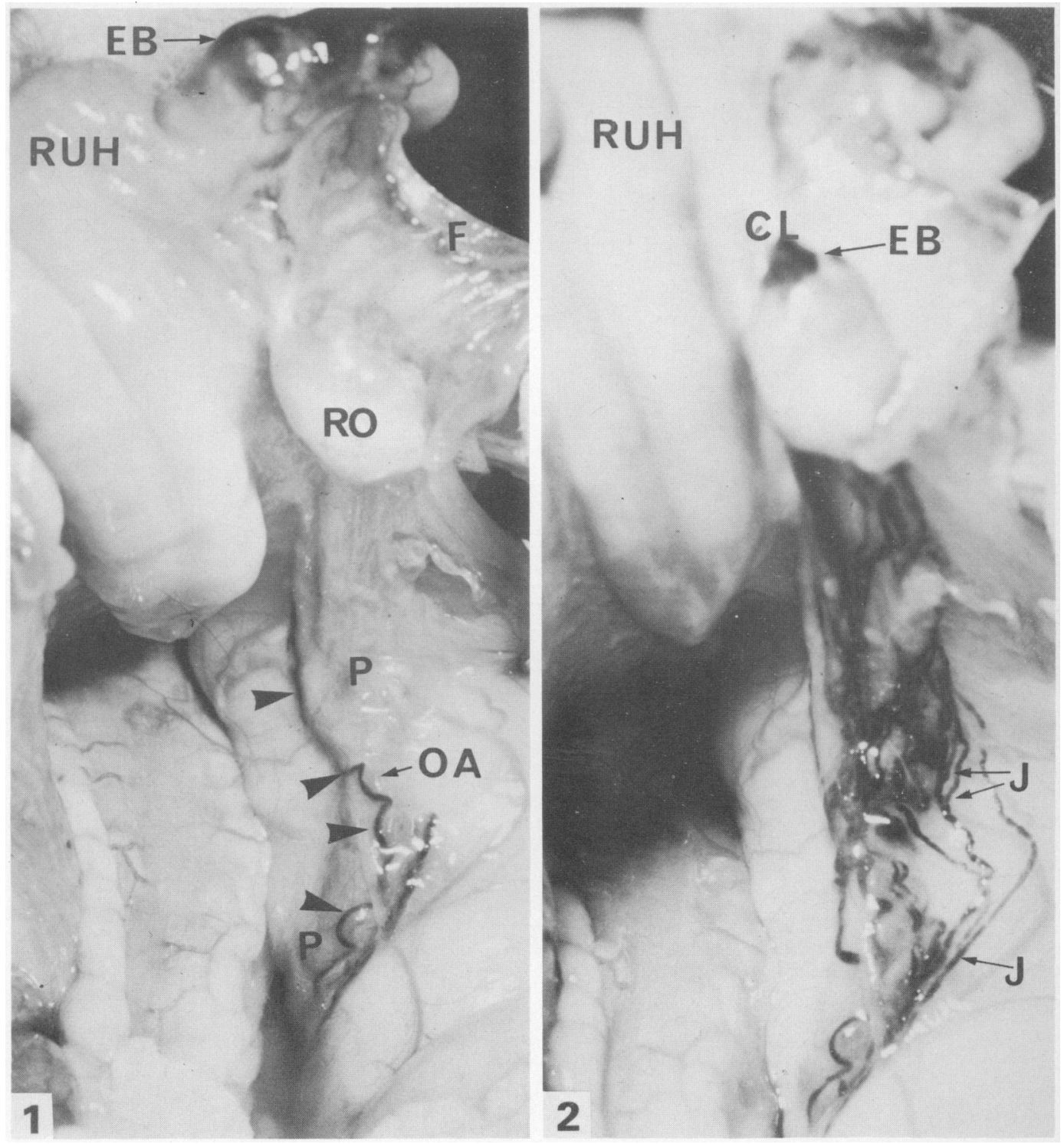

Lymphatic drainage of the right uterine horn (RUH), ovary (RO) and utero-ovarian vascular pedicle of a sheep at surgery. In this preparation injection of Evans blue (EB) into the right uterine wall (Fig. 1) revealed two lymphatic ducts in the utero-ovarian pedicle (P). One of these ducts (arrowheads) was closely associated with coils of the ovarian artery (OA). Subsequent injection of dye into the right corpus luteum (CL) revealed a complex network of valved lymphatic vessels (Fig. 2) which were previously undetectable. J, junctions between ovarian lymphatics; F, right oviduct which appears dark because of natural pigmentation.

(Facing p. 412.) 
uterine horn revealed lymphatics that drained towards the utero-ovarian pedicle where they collected into at least two main vessels (see Pl. 1, Fig. 1). These vessels contained valves at intervals of $2-5 \mathrm{~mm}$. After dye was injected into the ipsilateral corpus luteum, an additional series of lymphatics was displayed which frequently converged or ran in parallel to the uterine lymphatic vessels (Pl. 1, Fig. 2). When the ovary and the uterine horn were injected simultaneously with dyes of different colour it became apparent that the lymphatics from these two organs frequently anastomosed in the region of the pedicle, i.e. lymph became green when ducts containing Evans blue (ovarian or uterine injection) joined with those containing Alcian yellow (uterine or ovarian injection, respectively). The connections occurred almost exclusively along the distal two-thirds of the pedicle, and the utero-ovarian lymphatics thus formed were occasionally joined by other lymphatics of ovarian, uterine or mixed origin before reaching the lumbo-aortic node (or group of nodes), situated near the junction of the uterine artery and the dorsal aorta. This evidence for the presence of anastomoses was obtained in all four sheep examined after injection of two dyes.

There was considerable variation between animals in the arrangement of the uterine, ovarian and utero-ovarian lymphatics along the pedicle and it was not possible to identify all combinations of the interconnections in every preparation. Text-figure 1 (a) is a composite drawing of the arrangement of ovarian and uterine lymphatics in sheep. In all animals there was a very close association of certain uterine, ovarian and utero-ovarian lymphatics with the ovarian artery (Pl. 1, Fig. 1; Text-fig. 1a). A schematic representation of the interconnections of the lymphatic network observed in the utero-ovarian pedicle is shown in Text-fig. 1(b).

Lymphatics were also observed alongside the uterine artery when Evans blue was injected into the middle or lower-half of the uterine horn (Text-fig. 1a) in 2 Friesland sheep. Anastomosis between these uterine lymphatics and those draining the ovary also occurred because after injection of Alcian yellow into the ipsilateral ovary, a common duct containing green-coloured lymph was seen. This utero-ovarian lymphatic terminated at the medial iliac lymph node situated near the dorsal aorta and between the internal and external iliac arteries (Text-fig. 1a).

The utero-ovarian lymphatic networks in 2 goats resembled those observed in sheep.

There was no evidence for retrograde flow within uterine, ovarian or utero-ovarian lymphatic ducts.

\section{Lymph flow in cannulated lymphatics}

Lymph was collected by cannulation of a vessel located within, or adjacent to the utero-ovarian pedicle associated with the ovary containing a corpus luteum after an injection of Evans blue into the ipsilateral uterine horn. Flow continued for a period of 5 or more days in 7 of 10 sheep, and in 1 goat. Catheters remained patent an average of 10 days (range, 5-25 days). The mean flow was $2.91 \mathrm{ml} / \mathrm{h}$ (range $1.57-\sim 5.5 \mathrm{ml} / \mathrm{h}$ ) in 6 surgically prepared ewes studied between Days 15 and 31 post coitum (p.c.) (Table 1, Text-figs 3 and 4). In a 7th ewe (L 176) a bilateral ovulation had occurred and the ovary adjacent to the cannulated lymphatic was removed. In this ewe the flow rate of uterine lymph was $0.67 \mathrm{ml} / \mathrm{h}$ between Days 16 and 20 p.c. (Table 2, Text-fig. 4).

The average flow rate of lymph in a goat (No. E11) was $4.22 \mathrm{ml} / \mathrm{h}$ (mean of 25 daily observations) between Days 20 and 45 p.c. (Table 3, Text-fig. 2). Lymph flow rate showed no consistent diurnal variation after stabilization of the preparations, but it was usually reduced in the immediate post-operative period, and shortly before catheter occlusion (Text-figs 2, 3 and 4).

\section{Composition of afferent lymph}

Leucocytes. The number of leucocytes in utero-ovarian lymph rarely exceeded $200 / \mathrm{mm}^{3}$ in either species during the collection period (Tables 1, 2 and 3), except during the first 2-3 days 

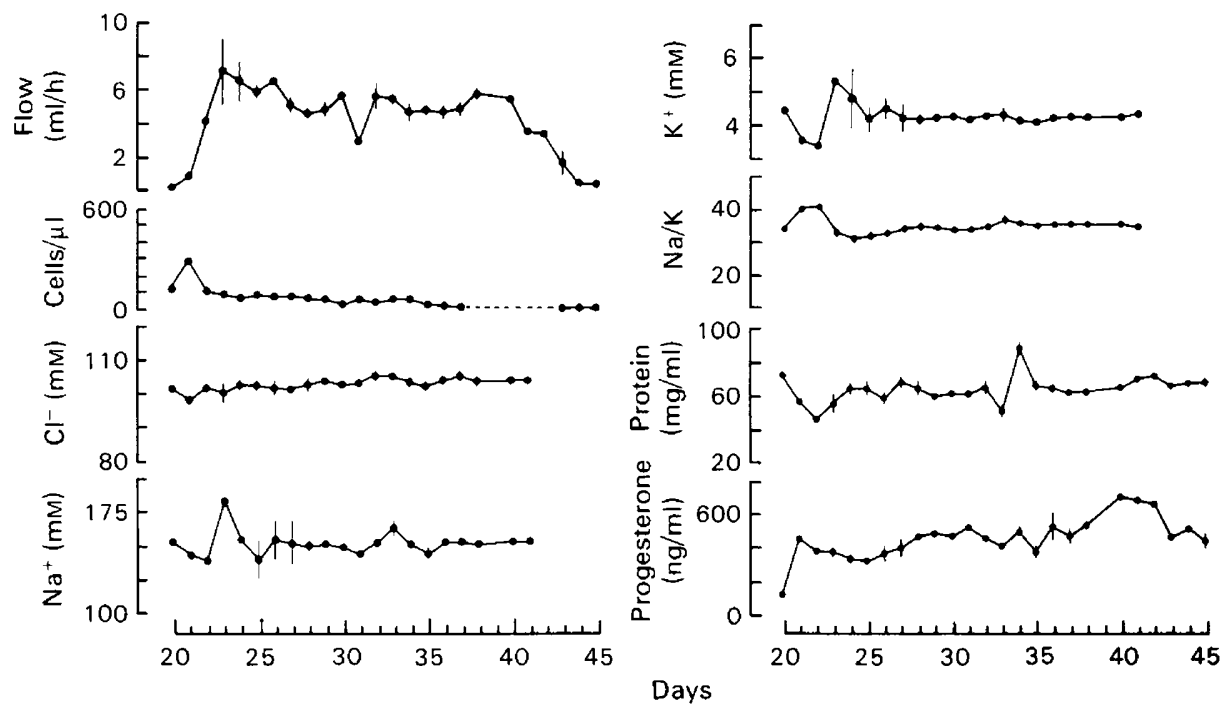

Text-fig. 2. Lymph flow rate, leucocyte, $\mathrm{Na}, \mathrm{K}, \mathrm{Cl}$, protein and progesterone concentrations and ratio of $\mathrm{Na} / \mathrm{K}$ in samples collected from Goat $\mathrm{E} 11$ mated 20 days before cannulation and which was found to have a fluid-filled uterus and persistent corpus luteum at autopsy. Lymph was collected from a utero-ovarian duct between Days 20 and 45 after mating. Each point represents the daily mean $(n=1-20$; s.e.m. bars omitted when $n<4)$. For leucocyte counts one estimation was performed each day. Note expanded scales for $\mathrm{Cl}, \mathrm{Na}, \mathrm{K}, \mathrm{Na} / \mathrm{K}$ and protein concentrations.

after surgery when a transient rise was frequently observed (Text-figs 2, 3 and 4). A notable exception was found in Sheep 443 (Text-fig. 4) in which a high mean count of $366 \times 10^{3} / \mathrm{ml}$ was observed. At autopsy on Day 35 p.c. a resorbing fetus with degenerating fetal membranes was found. The number of leucocytes in uterine lymph (Sheep L 176, Table 2, Text-fig. 4) was low $\left(77 \times 10^{3} / \mathrm{ml}\right)$.

Smears of cell sediments obtained after centrifugation of lymph samples collected at least 2 days after surgery revealed a leucocyte population of predominantly small lymphocytes $(94-100 \%)$ with the remainder mostly monocytes (0-6\%, Table 4). Eosinophils and polymorphonuclear leucocytes were rarely seen, except during the first 2 days after cannulation when there was a transient rise in the proportion of polymorphonuclear leucocytes in certain animals (Table 4). No smears were available for lymph obtained from Sheep 443 which had a resorbing fetus at Day 35.

Progesterone. Utero-ovarian lymph from vessels found alongside the utero-ovarian pedicle ipsilateral to the ovary bearing the corpus luteum contained high concentrations of progesterone $(481 \pm 195 \mathrm{ng} / \mathrm{ml}$ in sheep, $465 \pm 24 \mathrm{ng} / \mathrm{ml}$ in goats, Tables 1 and 3$)$. The highest mean concentration was found in Sheep X214 $(1346.7 \mathrm{ng} / \mathrm{ml})$, which had an average daily value as high as $1774 \mathrm{ng} / \mathrm{ml}$. Utero-ovarian lymph progesterone concentrations were between 10- and 1000-fold higher than those in peripheral plasma (Tables 1 and 3). Progesterone concentrations in utero-ovarian lymph were frequently low during the first few hours after operation, but thereafter remained relatively stable (Text-figs 2 and 3). An exception was seen in lymph from Sheep 443 (resorbing fetus) in which the progesterone concentration in lymph declined from about $100 \mathrm{ng} / \mathrm{ml}$ on Day 25 to near zero on Day 29 p.c. (Text-fig. 4). No consistent diurnal pattern occurred in lymph progesterone concentrations.

The progesterone concentration in uterine lymph collected from Sheep L176 (in which the ipsilateral ovary was removed at operation) was low $(1.67 \pm 0.31 \mathrm{ng} / \mathrm{ml}$; Text-fig. 4) and did not differ significantly from that in plasma $(1.28 \pm 0.23 \mathrm{ng} / \mathrm{ml}$; Table 2$)$.

Inorganic ions. The mean concentrations of $\mathrm{Na}, \mathrm{K}, \mathrm{Cl}$ and the ratio of $\mathrm{Na} / \mathrm{K}$ in lymph 


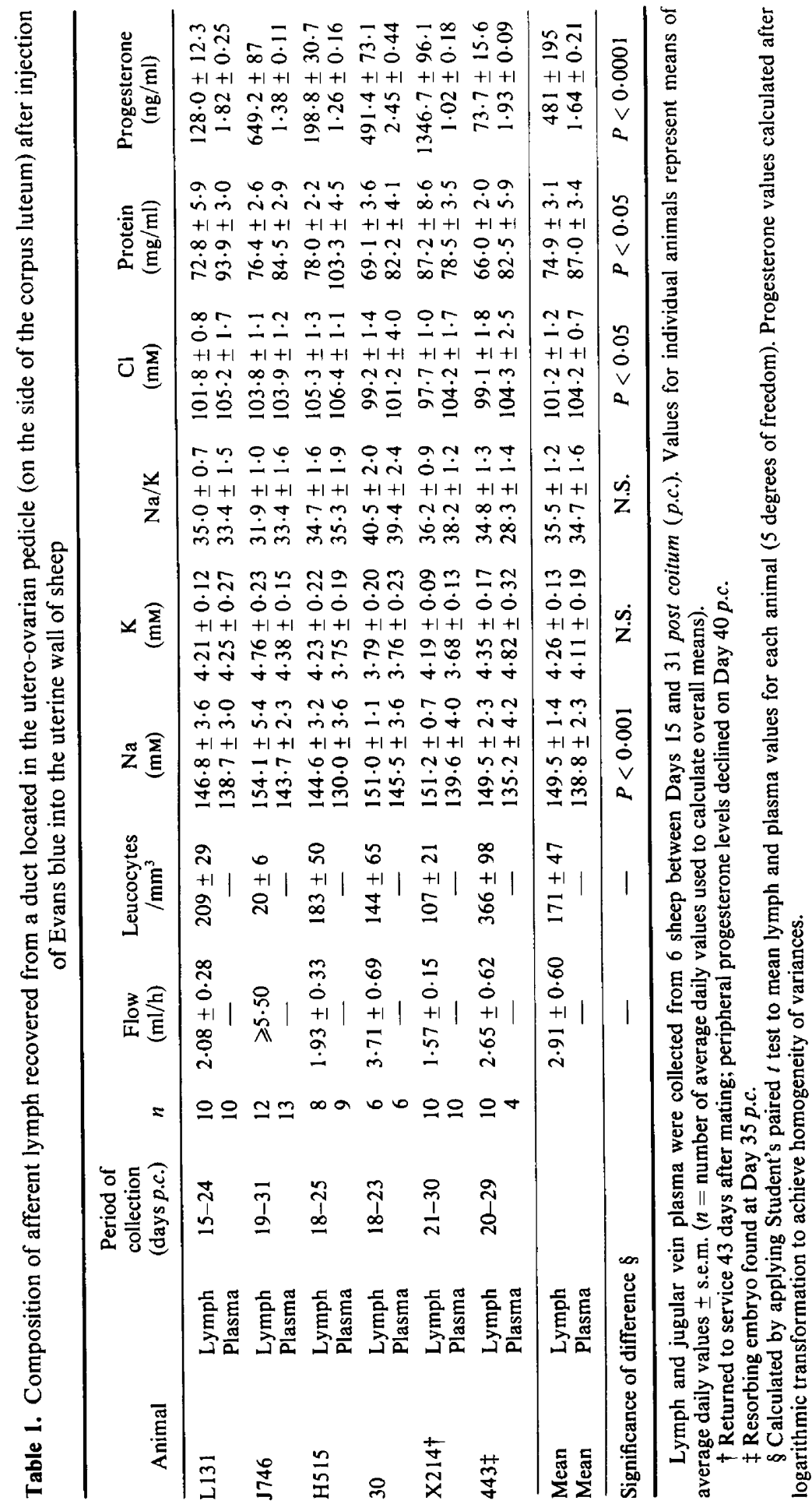


Table 2. Composition of uterine lymph collected after cannulation of a utero-ovarian lymphatic duct and removal of the ipsilateral ovary $\dagger$ and of plasma collected between Days 16 and 20 post coitum (p.c.) in Sheep L 176

\begin{tabular}{|c|c|c|c|c|c|c|c|c|c|c|c|}
\hline \multicolumn{2}{|c|}{ Animal } & $\begin{array}{l}\text { Period of } \\
\text { collection } \\
\text { (days p.c.) }\end{array}$ & $n$ & $\begin{array}{l}\text { Flow } \\
(\mathrm{ml} / \mathrm{h})\end{array}$ & $\begin{array}{l}\text { Leuco- } \\
\text { cytes } \\
/ \mathrm{mm}^{3}\end{array}$ & $\begin{array}{c}\mathrm{Na} \\
(\mathrm{mm})\end{array}$ & $\underset{(\mathrm{mM})}{\mathrm{K}}$ & $\mathrm{Na} / \mathrm{K}$ & $\underset{(\mathrm{mM})}{\mathrm{Cl}}$ & $\begin{array}{l}\text { Protein } \\
(\mathrm{mg} / \mathrm{ml})\end{array}$ & $\begin{array}{c}\text { Pro- } \\
\text { gesterone } \\
(\mathrm{ng} / \mathrm{ml})\end{array}$ \\
\hline L176 & $\begin{array}{l}\text { Lymph } \\
\text { Plasma }\end{array}$ & $16-20$ & 5 & $\begin{array}{c}0.67 \pm \\
0.17 \\
-\end{array}$ & $\begin{array}{l}77 \pm \\
28 \\
-\end{array}$ & $\begin{array}{c}148.2 \pm \\
1.1 \\
139.0 \pm \\
5.8\end{array}$ & $\begin{array}{c}4.38 \pm \\
0.19 \\
4.02 \pm \\
0.39\end{array}$ & $\begin{array}{c}34.2 \pm \\
1.8 \\
35.4 \pm \\
2.7\end{array}$ & $\begin{array}{c}97 \cdot 7 \pm \\
3 \cdot 2 \\
105 \cdot 3 \pm \\
3 \cdot 2\end{array}$ & $\begin{array}{c}79.9 \pm \\
4.5 \\
89.1 \pm \\
3.0\end{array}$ & $\begin{array}{c}1.67 \pm \\
0.31 \\
1.28 \pm \\
0.23\end{array}$ \\
\hline \multicolumn{6}{|c|}{ Significance of difference } & N.S. & N.S. & N.S. & N.S. & N.S. & N.S. \\
\hline
\end{tabular}

Values represent the means of average daily values \pm s.e.m. $(n=$ number of average daily values used to calculate means).

† Bilateral ovulations and so pregnancy was maintained by progesterone from the contralateral ovary.

¥ Calculated by applying Student's $t$ test to average daily lymph and plasma values ( 7 degrees of freedom).

Table 3. Composition of utero-ovarian lymph collected after cannulation of a utero-ovarian lymphatic duct ipsilateral to the ovary bearing a corpus luteum and of jugular venous plasma collected between Days 20 and 45 post coitum ( $p$.c.) in Goat E11

\begin{tabular}{|c|c|c|c|c|c|c|c|c|c|c|}
\hline & $\begin{array}{l}\text { Period of } \\
\text { collection } \\
\text { (days p.c.) }\end{array}$ & $n \ddagger$ & $\begin{array}{l}\text { Flow } \\
(\mathrm{ml} / \mathrm{h})\end{array}$ & $\begin{array}{l}\text { Leuco- } \\
\text { cytes } \\
/ \mathrm{mm}^{3}\end{array}$ & $\underset{(\mathrm{mM})}{\mathrm{Na}}$ & $\underset{(\mathrm{mM})}{\mathrm{K}}$ & $\mathrm{Na} / \mathrm{K}$ & $\underset{(\mathrm{mM})}{\mathrm{Cl}}$ & $\begin{array}{l}\text { Protein } \\
(\mathrm{mg} / \mathrm{ml})\end{array}$ & $\begin{array}{c}\text { Pro- } \\
\text { gesterone } \\
(\mathrm{ng} / \mathrm{ml})\end{array}$ \\
\hline Lymph & \multirow[t]{2}{*}{$20-45$} & $21-25$ & $\begin{array}{c}4.22 \pm \\
0.40\end{array}$ & $71 \pm 13$ & $\begin{array}{c}152.7 \pm \\
2.0\end{array}$ & $\begin{array}{c}4.29 \pm \\
0.08\end{array}$ & $\begin{array}{c}35.7 \pm \\
0.4\end{array}$ & $\begin{array}{c}102.8 \pm \\
0.4\end{array}$ & $\begin{array}{c}64.7 \pm \\
1.6\end{array}$ & $\begin{array}{c}465 \cdot 2 \pm \\
24 \cdot 1\end{array}$ \\
\hline Plasma & & $18-22$ & - & - & $\underset{2.1}{142.7 \pm}$ & $\begin{array}{c}4.14 \pm \\
0.09\end{array}$ & $\begin{array}{c}34.6 \pm \\
0.6\end{array}$ & $\begin{array}{c}102.8 \pm \\
1.6\end{array}$ & $\begin{array}{c}82.2 \pm \\
2.9\end{array}$ & $\begin{array}{l}2.70 \pm \\
0.22\end{array}$ \\
\hline 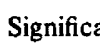 & differ & & & & 0.01 & N.S. & N.S. & N.S. & 0.001 & $<0.001$ \\
\hline
\end{tabular}

Values represent means of average daily values $\pm \operatorname{s.e.m.~(~} n=$ number of daily values used to calculate the mean).

$\dagger$ Calculated by applying Student's $t$ test to average daily lymph and plasma values (usually 41 d.f.).

¥ Values for some concentrations were not obtained for some samples.

Table 4. Differential counts of leucocytes present in uterine and utero-ovarian lymph collected from 6 sheep and 1 goat after a fertile mating.

\begin{tabular}{|c|c|c|c|c|c|c|c|c|}
\hline \multirow[b]{2}{*}{ Cell type ${ }^{\dagger}$} & \multirow{2}{*}{$\begin{array}{l}\text { Period after } \\
\text { cannulation } \\
\text { (days) }\end{array}$} & \multicolumn{6}{|c|}{ Sheep } & \multirow[b]{2}{*}{ Goat E11 } \\
\hline & & L131 & $\mathrm{J} 746$ & H5 15 & 30 & $\mathrm{X} 214$ & L176 & \\
\hline \multirow[t]{2}{*}{$\begin{array}{l}\text { Lymphocytes } \\
\text { (mostly small) }\end{array}$} & $<2$ & $91 \cdot 3(3)$ & $\begin{array}{c}100 \cdot 0 \\
(3)\end{array}$ & 99.7 (3) & N.D. & $85.9(4)$ & $\begin{array}{c}91 \cdot 1 \\
(3)\end{array}$ & $64 \cdot 5(1)$ \\
\hline & $>2$ & $\begin{array}{l}98 \cdot 7 \pm 0.5 \\
\quad(12)\end{array}$ & $\begin{array}{l}100 \cdot 0 \\
(5)\end{array}$ & $\underset{(6)}{98 \cdot 3 \pm 0.6}$ & $\frac{94 \cdot 4 \pm}{(5)} 3 \cdot 5$ & $\begin{array}{c}99 \cdot 2 \pm 0 \cdot 2 \\
(12)\end{array}$ & $\begin{array}{c}99.4 \\
(3)\end{array}$ & $\begin{array}{c}97 \cdot 3 \pm 0.6 \\
(37)\end{array}$ \\
\hline \multirow{2}{*}{$\begin{array}{l}\text { Polymorpho- } \\
\text { nuclear } \\
\text { leucocytes }\end{array}$} & $<2$ & $8 \cdot 1(3)$ & $0(3)$ & $0.2(3)$ & N.D. & $14 \cdot 1(4)$ & $\begin{array}{l}6 \cdot 8 \\
(3)\end{array}$ & $35 \cdot 5(1)$ \\
\hline & $>2$ & $0.2(12)$ & $0(5)$ & $0 \quad(6)$ & $0.2(5)$ & $0 \cdot 2(12)$ & $\begin{array}{l}0 \\
(3)\end{array}$ & $\begin{array}{c}1.5 \pm 0.4 \\
(37)\end{array}$ \\
\hline \multirow[t]{2}{*}{ Monocytes } & $<2$ & $0.6(3)$ & $0(3)$ & $0.2(3)$ & N.D. & $0 \quad$ (4) & $\begin{array}{l}2 \cdot 1 \\
(3)\end{array}$ & $0 \quad(1)$ \\
\hline & $>2$ & $1 \cdot 1(12)$ & $0(5)$ & $2 \cdot 1(6)$ & $5.4(5)$ & $0.6(12)$ & $\begin{array}{l}0.6 \\
(3)\end{array}$ & $\begin{array}{c}1.2 \pm 0.4 \\
(37)\end{array}$ \\
\hline
\end{tabular}

Values are given as \% of total leucocytes counted (mean \pm s.e.m., with number of smears examined in parentheses). When $n<5$ or when several zero values were obtained, only the mean is given.

† Leucocyte cell types other than lymphocytes, polymorphs and monocytes were rarely seen.

N.D. $=$ not determined. 

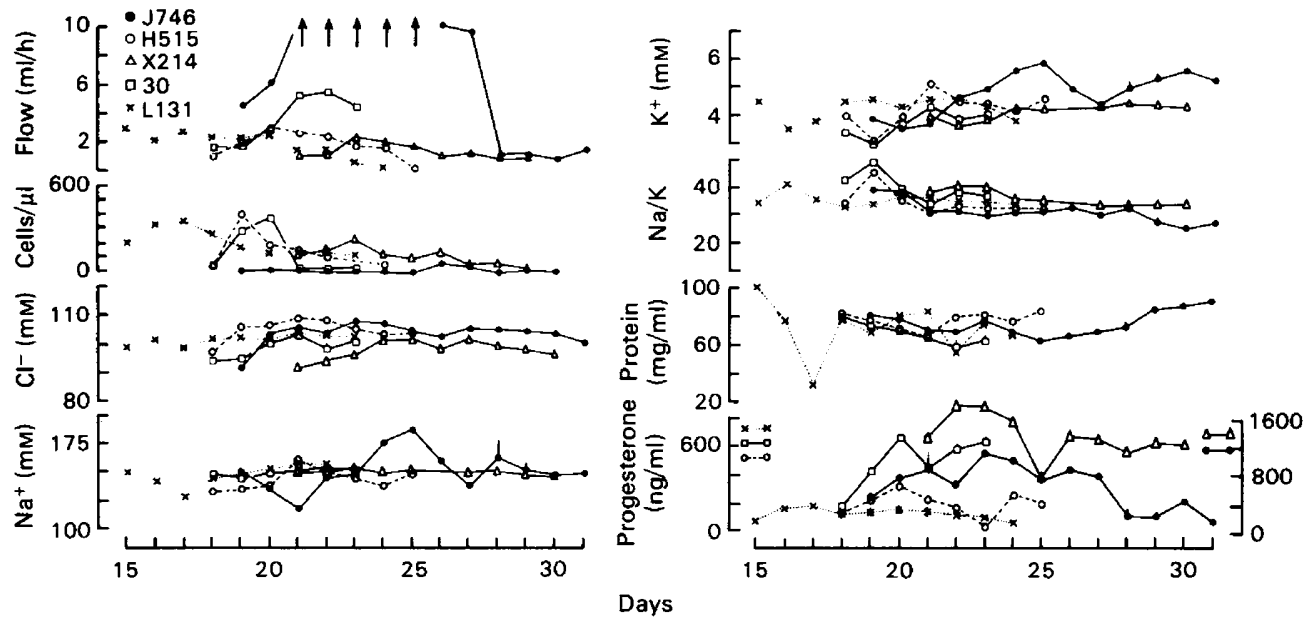

Text-fig. 3. Lymph flow rate, leucocyte, $\mathrm{Na}, \mathrm{K}, \mathrm{Cl}$, protein and progesterone concentrations and $\mathrm{Na} / \mathrm{K}$ ratio for utero-ovarian lymph samples collected from 5 ewes (Nos L131, 30, H515, X214 and J746) during early pregnancy. Note expanded scales as in Text-fig. 2. Note also that scale for progesterone values in lymph from Ewes X214 and J746 is $0-1600 \mathrm{ng} / \mathrm{ml}$, whereas that for lymph from the other three ewes is $0-800 \mathrm{ng} / \mathrm{ml}$.

obtained during the period of collection were similar in each animal (Tables 1,2 and 3), and they were relatively constant throughout a $24 \mathrm{~h}$ collection period. The ratio of $\mathrm{Na} / \mathrm{K}$ in lymph increased in some instances during the first 3 days after surgery but was not accompanied by a change in $\mathrm{Cl}$ concentration (Text-figs 2, 3 and 4). In sheep, the concentration of $\mathrm{Na}$ in utero-ovarian and uterine lymph was higher, whereas that of $\mathrm{Cl}$ was lower, compared with values measured in plasma from the same animals (Tables 1 and 2). In Goat E11 a similar
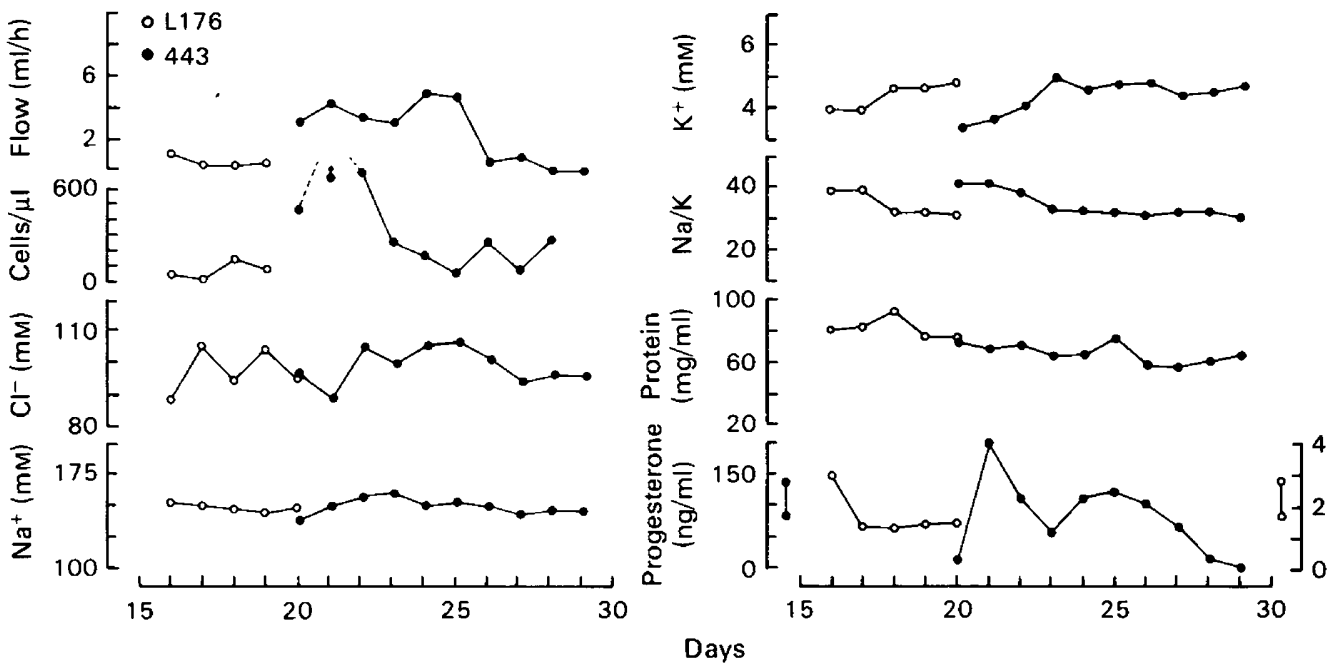

Text-fig. 4. Lymph flow rate, leucocyte count, $\mathrm{Na}, \mathrm{K}, \mathrm{Cl}$, protein and progesterone concentrations and $\mathrm{Na} / \mathrm{K}$ ratio in utero-ovarian samples collected from Ewe 443 and in uterine lymph collected from Ewe L176. Ewe 443 was found to have a resorbing embryo at Day 35 . In Ewe L176 uterine lymph was collected from a utero-ovarian lymphatic after removal of the ipsilateral ovary and pregnancy was maintained by the functional corpus luteum present in the contralateral ovary. Note the expanded scales as described in Text-fig. 2, and also that the progesterone scale for lymph from Ewe $\mathrm{L} 176$ is $0-4 \mathrm{ng} / \mathrm{ml}$ whereas that for Ewe 443 is $0-200$ $\mathrm{ng} / \mathrm{ml}$. 
increase in $\mathrm{Na}$ was observed, but there was no difference in $\mathrm{Cl}$ (Table 3). The concentration of $\mathrm{K}$, and the ratio of $\mathrm{Na} / \mathrm{K}$ was similar in lymph and plasma in both species.

Protein. In sheep, protein concentrations in utero-ovarian and uterine lymph varied from 66 to $87 \mathrm{mg} / \mathrm{ml}$ (Tables 1 and 2), showing no systematic variation throughout the collection period (Text-figs 3 and 4) or during a 24-h period. Similar results were found in Goat E11 (Table 3, Text-fig. 2). These concentrations in afferent lymph of sheep and goat, however, were lower than plasma protein concentrations in the same animals (Tables 1 and 3). In sheep the protein concentration in utero-ovarian lymph was $86.1 \%$ (Goat E11, 78.7\%), and in uterine lymph, $89.7 \%$, of that in plasma.

\section{Discussion}

The present study demonstrates the existence of a complex network of interconnected afferent lymphatics distributed along the utero-ovarian pedicle and within the mesometrium. Dyes of different colour (Evans Blue and Alcian yellow) were injected into the ovary and uterine wall to identify lymphatics which were normally transparent or even invisible against the vascular pedicle. This technique demonstrated the occurrence of several anastomoses between uterine and ovarian lymphatic ducts in all animals examined. These anastomoses resulted in greenish colouration in the lymphatics carrying mixed lymph. Confirmation that these ovarian-uterine lymphatic anastomoses were functional was obtained by the measurement of progesterone in lymph. Lymph recovered from ducts located in the utero-ovarian pedicle by injection of Evans blue into the uterine wall only, contained progesterone levels which were 1-3 orders of magnitude higher than those in peripheral plasma when the ipsilateral ovary contained a functional corpus luteum. It is improbable that the high concentration of progesterone was derived from the gravid uterus because the synthesis of progesterone by the conceptus has not been detected before about Day 50 in the sheep (Ricketts \& Flint, 1980), and about Day 130 in the goat (Sheldrick, Ricketts \& Flint, 1980). Moreover the progesterone values were similar to those obtained by Lindner et al. (1964) for ovarian lymph. Uterine lymph collected in the present study after excluding any ovarian contribution by ipsilateral ovariectomy contained a progesterone concentration which was similar to that in peripheral plasma. Thus, whereas colour lymphography was used to identify a lymphatic outfiow from the uterine horns, high progesterone values in lymph revealed that there was also an ovarian contribution. The ovarian contribution in these mixed samples was presumably derived from ovarian-uterine lymphatic anastomoses proximal to the site of cannulation which were undetectable at the time of operation.

The functional significance of the complex utero-ovarian lymphatic network is obscure. The competence of multiple bicuspid values in ovarian and uterine lymphatics prevented retrograde flow of lymph or retrograde injection of dye, so that direct transfer of substances between the uterus and ovary via the lymphatic ducts was prevented. A similar conclusion was reached by Meckley \& Ginther (1969). However, certain utero-ovarian lymphatic ducts were found closely associated with the ovarian artery. Their anatomical disposition suggests an additional route for the countercurrent diffusion of PGF- $2 \alpha$ to the ovarian blood supply during the normal oestrous cycle in sheep and goats. The quantitative significance of PGF- $2 \alpha$ secretion into uterine lymphatics in non-pregnant and pregnant animals remains to be established.

Values for the composition and flow rate of mixed afferent lymph require cautious interpretation because the relative contributions of uterine and ovarian lymph to the collected samples is not known. Furthermore, whereas the majority of visible lymphatics were occluded in the utero-ovarian pedicle, the establishment of collaterals after surgery could provide an alternative pathway for lymph flow. The flow rates reported here probably therefore represent minimum values. Protein concentrations in utero-ovarian lymph were about $78-86 \%$ of plasma values, compared with $73 \%$ for ovarian lymph reported by Morris \& Sass (1966). This is 
consistent with the highly permeable nature of the endothelial vessels of the corpus luteum (Morris \& Sass, 1966; Smith, McIntosh \& Morris, 1970). The observation that protein concentrations in uterine lymph were $89.7 \%$ of plasma values suggests a similar permeability for lymph collecting ducts within the uterus at this stage of pregnancy, although this finding requires confirmation since it was obtained in only one animal studied. The concentrations of $\mathrm{Na}, \mathrm{K}$ and $\mathrm{Cl}$ in afferent utero-ovarian and uterine lymph resembled those in plasma, confirming the integrity of the cannulated tissues, but consistent small differences were found in $\mathrm{Na}$, which was higher, and $\mathrm{Cl}$, which was lower, in lymph than in plasma. Such differences have rarely been observed for lymph collected from other organs, or from the thoracic duct (Yoffey \& Courtice, 1970).

The number of leucocytes in utero-ovarian lymph was low, and similar to values measured in afferent lymphatics draining the hind limb, kidney, testis and thyroid (Smith et al., 1970). The majority of cells consisted of lymphocytes with up to $6 \%$ monocytes and very low numbers of eosinophils and polymorphonuclear leucocytes. These values for cell counts are very similar to those reported for ovarian lymph in non-pregnant sheep (Smith et al., 1970) except that the number of monocytes was slightly higher (5-10\%) in the latter study. This difference, though small, may signify a lower monocyte concentration in lymph of pregnant sheep, or it may arise from our counting procedure which included only those cells dispersed on the smear while monocytes which aggregated with lymphocytes during centrifugation were discounted.

An implication of the above findings is that leucocytes which pass through the uterine horn adjacent to the ovary bearing a corpus luteum would be exposed to a high progesterone concentration in the lymphatic network and at both the lumbo-aortic and medial iliac nodes. Progesterone applied at a similar concentration in vitro suppressed mitogen-induced transformation of peripheral blood lymphocytes from sheep and goats (L. D. Staples, R. M. Binns \& R. B. Heap, unpublished observations). This is consistent with the hypothesis that progesterone (and certain other steroids) may have an immunoprotective function to ensure survival of the fetal allograft. However, the high concentration of progesterone in lymph does not alone explain the immunoprotection of the sheep or goat fetal allograft in early pregnancy. Progesterone given systemically (5-15 mg per day) to ovariectomized animals will successfully maintain pregnancy (Meites et al., 1957; Bindon, 1971; Cumming, Baxter \& Lawson, 1974), presumably without producing a high local concentration in utero-ovarian lymph. Moreover, when the membranes of the conceptus are present in the uterine horn contralateral to the ovary containing a corpus luteum (e.g. from about Day 15 onwards or after migration), leucocytes that pass through the horn would not be exposed to a high level of progesterone in the draining network or nodes during the initial stages of gestation. At later stages, however, the endocrine properties of the placenta assume greater importance and may result in high local concentrations of active compounds in tissue or draining nodes. The early conceptus actively metabolizes C-21 steroid precursors (Gadsby, 1979; Heap et al., 1981) and other C-21 steroids such as $20 \alpha$-dihydroprogesterone are present in lymph collected from lymphatics in the utero-ovarian pedicle of sheep during mid-gestation (Lindner et al., 1964; Lindner, 1966). It is not known whether they influence lymphocyte function, or antigen processing and presentation within the draining lymph node.

We thank Ms Diane Blakeley, Miss Maureen Hamon and Mr Richard Saunders for their technical assistance; Mr Robert Proudfoot and his staff for the care of experimental animals; and the Australian Wool Research Trust Funds for financial support.

\section{References}

Berry, J.W., Chappell, D.G. \& Barnes, R.B. (1946) Improved method of flame photometry. Ind. Eng. Chem. Anal. Ed. 18, 19-24.
Bindon, B.M. (1971) The role of progesterone in implantation in the sheep. Aust. J. biol. Sci. 24, 149-158. 
Casida, L.E. \& Warwick, E.J. (1945) The necessity of the corpus luteum for maintenance of pregnancy in the ewe. J. Anim. Sci. 4, 34-36.

Cumming, I.A., Baxter, R. \& Lawson, R.A.S. (1974) Steroid hormone requirements for the maintenance of early pregnancy in sheep: a study using ovariectomized adrenalectomized ewes. J. Reprod. Fert. 40, $443-446$.

Denamur, R. \& Martinet, J. (1955) Effects de l'ovariectomie chez le brebis pendant la gestation. C. r. Séanc. Soc. Biol. 149, 2105-2107.

Drummond-Robinson, G. \& Asdell, S.A. (1926) The relation between the corpus luteum and the mammary gland. J. Physiol, Lond. 61, 608-614.

Gadsby, J.E. (1979) Oestrogen synthesis and steroid metabolism by blastocyst, embryonic and maternal tissues of the pig, cow and sheep during early pregnancy. $\mathrm{Ph} . \mathrm{D}$. thesis, University of Cambridge.

Goding, J.R. (1974) The demonstration that PGF P $_{2 u}$ is the uterine luteolysin in the ewe. J. Reprod. Fert. 38, 261-271.

Habel, R.E. (1964) Guide to the Dissection of Domestic Ruminants, pp. 52-54. (Published by R. E. Habel, distributed by Edwards Brothers, Inc., Ann Arbor, Michigan.)

Heap, R.B., Flint, A.P.F., Hartman, P.E., Gadsby, J.E., Staples, L.D., Ackland, N. \& Hamon, M. (1981) Oestrogen production in early pregnancy. $J$. Endocr. 89, $77 P-94 P$.

Kotwica, J. (1980) Mechanism of prostaglandin F-2 $\alpha$ penetration from the horn of the uterus to the ovaries in pigs. J. Reprod. Fert. 59, 237-241.

Land, R.B., Baird, D.T. \& Scaramuzzi, R.J. (1976) Dynamic studies of prostaglandin F-2 $\alpha$ in the utero-ovarian circulation of the sheep. J. Reprod. Fert. 47, 209-214.

Lascelles, A.K. \& Morris, B. (1961) Surgical techniques for the collection of lymph from unanaesthetized sheep. Q. Jl exp. Physiol. 46, 199-205.

Lindner, H.R. (1966) Participation of lymph in the transport of gonadal hormones. Excerpta Medica Int. Congr. Ser. 132, 821-827.

Lindner, H.R., Sass, M.B. \& Morris, B. (1964) Steroids in the ovarian lymph and blood of conscious ewes. $J$. Endocr. 30, 361-376.
Linzell, J.L. \& Heap, R.B. (1968) A comparison of progesterone metabolism in the pregnant sheep and goat: sources of production and an estimation of uptake by some target organs. J. Endocr. 41, 433-438.

Lowry, O.H., Rosebrough, N.J., Farr, A.L. \& Randall, R.J. (1951) Protein measurement with the Folin phenol reagent. J. biol. Chem. 193, 265-275.

McCracken, J.A., Carlson, J.C., Glew, M.E., Goding, J.R., Baird, D.T., Green, K. \& Samuelsson, B. (1972) Prostaglandin $\mathrm{F}_{2 u}$ identified as a luteolytic hormone in the sheep. Nature, New Biol. 238, 129-134.

Meckley, P.E. \& Ginther, O.J. (1969) Lymphatic drainage of uterus and ovaries in the ewe. J. Anim. Sci. 29, 195.

Meites, J., Webster, H.D., Young, F.W., Thorp, F., Jr \& Hatch, R.N. (1951) Effects of the corpora lutea removal and replacement with progesterone on pregnancy in goats. J. Anim. Sci. 10,411-416.

Morris, B. \& Sass, M.B. (1966) The formation of lymph in the ovary. Proc. R. Soc. B 164, 577-591.

Ricketts, A.P. \& Flint, A.P.F. (1980) Onset of synthesis of progesterone by ovine placenta. $J$. Endocr. 86, 337-347.

Ricketts, A.P., Galil, A.K.A., Ackland, N., Heap, R.B. \& Flint, A.P.F. (1980) Activation by corticosteroids of steroid metabolizing enzyme in ovine placental explants in vitro. J. Endocr. 85, 457-469.

Sheldrick, E.L., Mitchell, M.D. \& Flint, A.P.F. (1980) Delayed luteal regression in ewes immunized against oxytocin. J. Reprod. Fert. 59, 37-42.

Sheldrick, E.L., Ricketts, A.P. \& Flint, A.P.F. (1980) Placental production of progesterone in ovariectomized goats treated with a synthetic progestagen to maintain pregnancy. J. Reprod. Fert. 60, 339-348.

Short, R.V. \& Moore, N.W. (1959) Progesterone in blood. V. Progesterone and 20a-hydroxypregn-4en-3-one in the placenta and blood of ewes. $J$. Endocr. 19, 288-293.

Smith, J.B., MeIntosh, G.H. \& Morris, B. (1970) The traffic of cells through tissues: a study of peripheral lymph in sheep. J. Anat. 107, 87-100.

Yoffey, J.M. \& Courtice, F.C. (1970) Lymphatics and the Lymphomyeloid Complex. Academic Press, New York. 